\title{
Przesłanie polityczne encykliki Centesimus annus ${ }^{1}$
}

Centesimus annus podejmuje kwestie stricte polityczne w dwóch podejściach: w rozdziale zatytułowanym „Rok 1989”, który jest w pewnym sensie analitycznym spojrzeniem wstecz, oraz $\mathrm{w}$ rozdziale „Państwo i kultura", który jest spojrzeniem wybiegającym do przodu. Mamy zatem $\mathrm{z}$ jednej strony analizę moralną przyczyn upadku komunizmu, z drugiej - refleksję nad tym, w jaki sposób budować praworządne państwo po komunizmie. Rok 1989 papież postrzega jako rok graniczny (annus mirabilis) zarówno z punktu widzenia historycznego - upadek systemu totalitarnego, jak i z punktu widzenia teologicznej refleksji nad polityką. W analizie sytuacji kluczowe wydaje się stwierdzenie, że system polityczny, który właśnie się rozpadł, został ustanowiony w wyniku wojny światowej i spodziewano się, że jedynie w podobnym trybie może dokończyć swojego żywota². Stąd obawa Zachodu przed wybuchem kolejnej wojny światowej działała na rzecz konserwacji komunizmu. Tymczasem jego dekompozycja nastąpiła właściwie bez jednego wystrzału. Czy oznacza to, że odkryto nowe prawo transformacji ustrojowej? Czy uzyskano dostęp do nowej wiedzy z zakresu nauk politycznych o znaczeniu uniwersalnym?

W papieskiej analizie przyczyn upadku systemu komunistycznego główny argument jest natury moralnej. „Wydarzenia roku 1989 są przykładem zwycięstwa woli dialogu i ducha ewangelicznego w zmaganiach z przeciwnikiem, który nie czuje się związany zasadami moralnymi;

Artykuł zawiera wiele odniesień do myśli wyrażonych pierwotnie w: P. Mazurkiewicz, Etyczne podstawy demokracji według Jana Pawła II, w: Po przełomie. Przełom wieku w kulturze - kultura na przełomie wieków, red. A. Żylińska, A. Skrendo, Szczecin 2001, s. 19-30.

2 Zob. CA 23. 
są zatem przestrogą dla tych, którzy w imię realizmu politycznego chcą usunąć $\mathrm{z}$ areny politycznej prawo i moralność”. to jedyny powód rozpadu komunistycznego imperium, zdaniem papieża, to właśnie ten argument decyduje o pokojowym charakterze przemian. Uprawomocnia to twierdzenie, że „decydującym czynnikiem tego procesu była działalność Kościoła”.

\section{Realizm polityczny}

Kluczowe wydaje się rozumienie realizmu politycznego. Od polityków wszak wymaga się od zawsze, aby stąpali mocno po ziemi. W imię tak zwanej Realpolitik decydowano się na wiele kompromisów, które były moralnie wątpliwe. Realizm rozumiano w tym przypadku jako konieczność rozstania się z etycznymi zasadami. Etyka miałaby być z natury swojej nieżyciowa. Wchodzimy tutaj w wielki spór między klasycznym arystotelesowskim rozumieniem polityki a nurtem zapoczątkowanym przez Machiavellego. Stagiryta odróżniał politykę jako naukę teoretyczną od polityki jako umiejętności rządzenia państwem. Politykę jako umiejętność rządzenia państwem, którą nazywał także polityką w znaczeniu szerszym, ściśle wiązał z rozsądkiem, przeprowadzając zarazem jej wewnętrzny podział na sztukę prawodawczą oraz politykę w znaczeniu węższym, czyli sztukę naradzania się i sztukę sądową́. Polityka jest tu nie tylko ściśle powiązana $\mathrm{z}$ rozsądkiem (cnotą intelektualną z grupy cnót praktycznych), ale także zaliczona do obszaru sztuki ( $\tau \dot{\varepsilon} \chi \nu \eta)$. Słowo $\tau \dot{\varepsilon} \chi \nu \eta$ ma u Stagiryty bardzo specyficzne znaczenie, gdyż obejmuje zarówno teoretyczną wiedzę, jak i umiejętności praktyczne, które tę wiedzę czynią

3 CA 25.

4 CA 22.

5 „Polityka (umiejętność rządzenia państwem) i rozsądek są właściwie tą samą trwałą dyspozycją, ale ich sposób przejawiania się jest różny. W polityce (w znaczeniu obszerniejszym) ta jej część, która ma rolę jakby kierowniczą, spełnia funkcję ustawodawczą; ta zaś, która dotyczy spraw jednostkowych, nosi wspólną nazwę polityki (w znaczeniu ściślejszym). Posiada ona charakter praktyczny i ma do czynienia z namysłem. Uchwała bowiem jest czymś, co należy wykonać jako akt jednostkowy. Dlatego to tylko o przedstawicielach drugiej z tych sztuk mówi się, iż uprawiają politykę; bo tylko oni coś wykonują, tak jak rękodzielnicy" (Arystoteles, Etyka nikomachejska, w: tenże, Dzieła wszystkie, t. 5, Warszawa 1996, s. 201). 
dla życia użyteczną ${ }^{6}$. Polityka zatem jako sztuka rządzenia państwem wymaga zarówno wiedzy na temat dobra wspólnego, jak i praktycznych umiejętności oraz psychicznych predyspozycji. Jest tworzeniem, co oznacza, że niezbędna staje się tu pewna wiedza teoretyczna, ale także wiedza praktyczna, osobista, zrodzona $\mathrm{z}$ doświadczenia. Z uwagi na właściwe zrozumienie poglądu Arystotelesa należy podkreślić istotną różnicę między koncepcją polityki jako sztuki a - przypisywaną Machiavelle$\mathrm{mu}$ - koncepcją polityki rozumianej jako technika sprawowania władzy. „Sztuka polityki wpisuje się w naturalny porządek polityki, którego celem - pisze Philippe Bénéton - jest osiągnięcie pełni przez ludzką naturę. Technika natomiast pozbawiona jest jakiejkolwiek wewnętrznej celowości, używana jest zgodnie z upodobaniem tego, kto się nią posługuje, i zgodnie ze sposobami, które wynikają bardziej z ducha geometrii niż $\mathrm{z}$ ducha celowości. Polityka jako technika jest racjonalnym instrumentem w służbie celów, jakie człowiek stawia sam sobie. Filozofia klasyczna i chrześcijańska okresu klasycznego rozwijają koncepcję teleologiczną polityki, podczas gdy filozofia nowożytna jej koncepcję instrumentalną"”. Polityka jako sztuka, mimo iż należy do sfery praktyki i wiąże się ściśle z wytwarzaniem, „uzupełnianiem tego, czego natura nie może urzeczywistnić" ${ }^{8}$, jest jednak czymś różnym od techniki rozumianej jako niczym nieskrępowane tworzenie zgodnie z zamysłem człowieka. Chodzi o takie tworzenie, które służy osiągnięciu przez człowieka (jako istotę społeczną) celu wpisanego w jego naturę. Różnica jest konsekwencją przyjętej teleologicznej wizji człowieka oraz uznania dobra wspólnego za cel politycznej aktywności, co - z uwagi na kierunkowe jedynie rozumienie kategorii dobra wspólnego - pozostawia człowiekowi swobodę działania politycznego, ale nie dowolność.

Polityka marksistowska jest typowym, choć nie jedynym przykładem instrumentalnego traktowania polityki. Stawia sobie cele, lecz - w imię swoiście pojmowanego realizmu - lekceważy zarówno prawo, jak i zasady moralne9. Jan Paweł II stwierdza, że owo „lekceważenie [tu następuje

6 Por. K. Narecki, Słownik terminów Arystotelesowych, w: Arystoteles, Dzieła wszystkie, t. 8, Warszawa 1990, s. 116; Arystoteles, Metafizyka, w: tenże, Dzieła wszystkie, t. 2, Warszawa 1990 , s. 617.

7 P. Bénéton, Introduction à la politique, Paris 1997, s. 13.

Arystoteles, Fizyka, w: tenże, Dzieła wszystkie, t. 2, s. 60.

9 Por. CA 25. 
odwołanie się do argumentu antropologicznego - P. M.] natury człowieka, stworzonego dla wolności, jest nie tylko niedozwolone z punktu widzenia etycznego, ale i praktycznie niemożliwe"10. Nic innego, jak właśnie realizm domaga się poszanowania moralności i prawa.

\section{Polityka jako świecka religia}

Drugim elementem papieskiej analizy jest odpowiedź na pytanie o relację między religią a polityką. W myśli kard. Josepha Ratzingera/Benedykta XVI ogniwem pośrednim w tej relacji jest etyka. Inaczej mówiąc, religia nie wyznacza celów polityce, a jedynie zadaje wartości, dostarcza kryteriów moralnej oceny działań politycznych. Benedykt XVI w westminsterskim przemówieniu jeszcze wyostrzył tę argumentację. Religia nie dostarcza polityce wartości, tak jakby rozum naturalny nie był w stanie ich odkryć swoją własną siłą. Pełni jedynie rolę korekcyjną, tzn. pomaga rozumowi naturalnemu upewnić się co do poprawności własnych wyborów poprzez ich konfrontację z wynikami osiągniętymi przez rozum religijny, czerpiący także z danych objawienia. W zakresie podstawowych wartości wyniki obu procesów rozumowania powinny być zbieżne, gdyż Bóg, który się objawia, jest także Stwórcą człowieka, jako bytu wyposażonego w rozum naturalny ${ }^{11}$. Tymczasem, zauważa Jan Paweł II, gdy rozum - za sprawą ateizmu - traci świadomość istnienia transcendentnej perspektywy ludzkiego działania, popada w iluzję odnośnie do własnych zdolności poznawczych. Brak krytycyzmu co do wiarygodności wyników ludzkiego rozumowania jest charakterystyczny dla całej pooświeceniowej filozofii. Zapoznaje się w niej prawdę o byciu stworzeniem oraz o grzechu pierworodnym, którego skutki objawiają się także w obszarze racjonalności człowieka. W konsekwencji uznaje się człowieka za jedynego kreatora prawdy, której nadaje się charakter absolutny. Oparta na takiej wizji polityka staje się czymś w rodzaju „świeckiej religii”, której krzewiciele nie zawahają się nawet użyć przemocy w celu jej propagowania. „Gdy ludzie sądzą, że posiedli tajemnice doskonałej organizacji społecznej, która eliminuje zło - pisze Jan Paweł II - sądzą także, że mogą stosować

\footnotetext{
${ }^{10}$ Tamże.

${ }^{11}$ Por. P. Mazurkiewicz, Niepolityczna polityczność Kościoła, w: 50 lat później. Posoborowe dylematy wspótczesnego Kościoła, red. J. Grosfeld, Warszawa 2014, s. 131-145.
} 
wszelkie środki, także przemoc czy kłamstwo, by ją urzeczywistnić. Polityka staje się wówczas «świecką religią», która łudzi się, że buduje w ten sposób raj na ziemi”"12. Człowiek zdrowo myślący powinien co prędzej zdystansować się do takich pomysłów. Kościół przypomina politykom, że w ludzkie dzieje nieuchronnie wpisana jest „tajemnica bezbożności” (misterium iniquitatis), trwa w nich nieustanna walka między dobrem i złem, która rozstrzygnięta będzie dopiero u końca czasów. „Roszcząc sobie prawo do formułowania tego sądu [do ostatecznego rozprawienia się ze złem - P. M.] już teraz, człowiek stawia się na miejscu Boga i sprzeciwia się Jego cierpliwości”'13. Dojrzała polityka powinna stronić od przekształcania się w eschatologię polityczną, dojrzałego zaś polityka cechować powinny cnoty umiarkowania i cierpliwości, które pozwalają odróżnić dobro, które jest w zasięgu ludzkiego wysiłku, od tego, które może być urzeczywistnione jedynie mocą Boga w innym eonie ${ }^{14}$.

\section{Z sympatią o demokracji}

W Centesimus annus papież wyraża się z sympatią o demokracji. „Kościół docenia demokrację" - pisze $^{15}$. Ustrój ten postrzegany jest przez niego jako alternatywa dla totalitaryzmu. Papież widzi świat po komunizmie w sposób binarny. Po jednej stronie jest totalitaryzm i autorytaryzm, najprawdopodobniej jako forma posttotalitarna ${ }^{16}$, po drugiej - demokracja. W tekście encykliki nie padają nazwy innych form ustrojowych. Tym jednak, co łączy totalitaryzm i zwolenników demokracji, jest masowy charakter obu tych kategorii. Ustrój totalitarny nie jest możliwy bez zaangażowania po jego stronie szerokich rzesz ludzi. „Dojście Hitlera do władzy było legalne z punktu widzenia zasady rządów większości i ani

12 CA 25.

13 Tamże.

${ }^{14}$ Por. J. Ratzinger, Kościół - ekumenizm - polityka, Warszawa-Poznań 1990, s. 198.

${ }^{15}$ CA 46. Stanowisko to wyrażone jest jeszcze bardziej zdecydowanie w adhortacji Ecclesia in Africa, gdzie czytamy: „[...] autentyczna demokracja, szanująca zasady pluralizmu, «powinna stać się jednym z podstawowych szlaków, po których Kościół idzie wraz ze swym ludem. [...] Świecki chrześcijanin walczący o demokrację w duchu Ewangelii jest znakiem Kościoła, który uczestniczy w budowie praworządnego państwa w całej Afryce»” (Jan Paweł II, Posynodalna adhortacja apostolska Ecclesia in Africa, 112).

16 Por. CA 29. 
on, ani Stalin nie potrafiliby utrzymać władzy nad wielkimi zbiorowościami ludzkimi, przetrwać kryzysów zewnętrznych i wewnętrznych oraz stawić czoła wielorakim niebezpieczeństwo, związanym $\mathrm{z}$ bezwzględną walką toczącą się w łonie partii, gdyby nie cieszyli się zaufaniem mas"17. Zarazem - zaznacza Jan Paweł II - to właśnie „rzesze robotników pozbawiły prawomocności ideologię, która chce przemawiać w ich imieniu”18. Trzeba zatem powiedzieć, że różnica między totalitaryzmem a demokracją nie zasadza się na liczebności grupy legitymizującej władzę. Dotyczy ona przede wszystkim sposobu sprawowania władzy. Hannah Arendt zwraca uwagę, że totalitaryzm wiąże się z umiejętnością mobilizacji mas, tzn. „ludzi pozornie biernych, których wszystkie inne partie uznały za zbyt apatycznych albo zbyt głupich na to, aby się nimi interesować", i którzy w związku z tym „nigdy przedtem nie pojawili się na scenie politycznej”"19. Demokracja natomiast powinna się opierać na mobilizacji dobrze poinformowanych obywateli, przy „milczącej aprobacie i tolerancji obojętnych i niemych warstw ludzi”"20 nazywanych motłochem. Kłopot w tym, że aby totalitaryzm mógł sięgnąć po władzę, niezbędne jest, aby do niewykształconych mas przyłączyli się także „ukąszeni” ideologicznie przedstawiciele elit społecznych, budując „chwilowy sojusz elity z motłochem" ${ }^{21}$.

Zacytowane zdanie o poparciu demokracji należy rozwinąć. „Kościół docenia demokrację - czytamy - jako system, który zapewnia udział obywateli w decyzjach politycznych i rządzonym gwarantuje możliwość wyboru oraz kontrolowania własnych rządów, a także - kiedy należy to uczynić - zastępowania ich w sposób pokojowy innymi”22. Wybór, kontrola i możliwość zmiany rządu należą zatem do istoty demokracji. Akceptacja pokojowej zmiany oznacza, że „demokraci”, utraciwszy władzę w wyniku demokratycznych wyborów, nie spiskują, ale spokojnie (choć zarazem aktywnie) oczekują na następne.

${ }_{17}$ H. Arendt, Korzenie totalitaryzmu, t. 2, tłum. D. Grinberg, M. Szawiel, Warszawa 1989, S. 31.

${ }^{18}$ CA 23.

19 H. Arendt, Korzenie totalitaryzmu, s. 38 .

${ }^{20}$ Tamże, s. 39.

${ }^{21}$ Tamże, s. 66.

${ }^{22}$ CA 46. 


\section{Krytycznie o demokracji}

Deklarując silne przywiązanie do demokracji, Jan Paweł II jest zarazem jednym z głównych jej krytyków. Z jego ust wielokrotnie padały szokujące w pierwszym momencie słowa wskazujące na niebezpieczną bliskość demokracji i totalitaryzmu. Papieska wizja demokracji z pewnością nie jest wizją polityczną, tzn. nie jest opowiedzeniem się po stronie szczegółowych rozwiązań instytucjonalnych, które - z jakiegoś tytułu - byłyby bliższe Kościołowi niż inne. „Kościół respektuje słuszną autonomię porządku demokratycznego - czytamy w Centesimus annus - i nie ma tytułu do opowiadania się za takim albo innym rozwiązaniem instytucjonalnym czy konstytucyjnym"23. Stosunkowo sprawnie funkcjonujące mechanizmy demokracji liberalnej nie są więc same w sobie kwestionowane przez papieża. Powstaje jednakże pytanie, czy demokrację wolno sprowadzać wyłącznie do zachowania pewnych formalnych procedur? Czy nie pojawia się wówczas groźba, że nie będzie już „autentyczną demokracją"24, a jedynie pozornie przypominać będzie formę sprawowania władzy opisywaną przez Locke’a, Monteskiusza, Madisona, Hamiltona czy Maritaina? „Mógłby ktoś pomyśleć - czytamy w Evangelium vitae że również taka funkcja demokracji, z braku czegoś lepszego, ma swoją wartość, jako że służy pokojowi społecznemu. Nawet uznając pewien element prawdy w takiej ocenie, trudno nie zauważyć, iż bez zakorzenienia w obiektywnej moralności nawet demokracja nie może zapewnić trwałego pokoju, tym bardziej że pokój, jeśli jego miarą nie są wartości takie jak godność każdego człowieka i solidarność wszystkich ludzi, nierzadko okazuje się pozorny" ${ }^{25}$. Papieska refleksja zawarta w Centesimus annus, a potem rozwijana w Evangelium vitae odwołuje się do rozróżnienia demokracji formalnej/proceduralnej i substancjalnej, mimo iż terminy te nie padają w tych tekstach. Nie chodzi tu o jakąś deprecjację demokracji formalnej. Demokratyczne instytucje stanowią wypracowaną z trudem w ciągu dziejów część dobra wspólnego. Niemniej demokracja rozumiana wyłącznie proceduralnie nie byłaby godna miana demokracji.

\footnotetext{
${ }^{23} \mathrm{CA} 47$.

${ }^{24} \mathrm{CA} 46$.

${ }^{25}$ EV 70.
} 
Specyficznie „kościelnym” wkładem w rozwój demokracji jest refleksja nad jej etycznymi fundamentami. Kościół poszukuje odpowiedzi na pytanie o to, co w istocie różni „prawdziwą" i „pozorną" demokrację, tę formę sprawowania władzy, która jest próbą konkretyzacji odpowiedzi na najgłębsze pragnienia człowieka, od tej, która wszystkie ludzkie sprawy sprowadza do kryterium ilościowego.

Charakterystyczne dla Jana Pawła I jest powiązanie demokracji ze światem wartości. Demokratyczne procedury mają wymiar wyłącznie instrumentalny. Są jedynie środkiem służącym społeczeństwu do osiągnięcia zamierzonych przez nie celów. „Jest ona zasadniczo «porządkiem»- pisze Jan Paweł II - i jako taka środkiem do celu, a nie celem. Charakter «moralny» demokracji nie ujawnia się samoczynnie, ale zależy od jej zgodności z prawem moralnym, któremu musi być podporządkowana, podobnie jak każda inna ludzka działalność: zależy zatem od moralności celów, do których zmierza, i środków, jakimi się posługuje. Jeśli wartość demokracji jest dziś prawie powszechnie uznawana, to należy w tym widzieć pozytywny «znak czasów», co również stwierdził wielokrotnie Urząd Nauczycielski Kościoła. Ale wartość demokracji rodzi się albo zanika wraz z wartościami, które ona wyraża i popiera [...]"26.

\section{Relatywizm aksjologiczny a tyrania większości}

Powstaje pytanie o to, jakie konkretnie wartości powinny stanowić fundament demokracji oraz gdzie znajduje się ich źródło, tzn. skąd wiadomo, że to właśnie ten zestaw wartości jest właściwy. Skoro demokracja opiera się na zasadzie większości, można by wnosić, że również w dziedzinie aksjologii prawomocność wyboru znajdzie swoje uzasadnienie w woli większości. Wydaje się, że takie podejście dominuje obecnie w świecie polityki. „W każdym razie, we współczesnej kulturze demokratycznej szeroko rozpowszechnił się pogląd, wedle którego porządek prawny społeczeństwa powinien ograniczać się do utrwalania i przyswajania sobie przekonań większości i w konsekwencji winien być zbudowany wyłącznie na tym, co większość obywateli stosuje i uznaje za moralne"27. Głównym źródłem tego poglądu jest sceptycyzm poznawczy, to znaczy

\footnotetext{
26 Tamże.

${ }^{27}$ EV 69.
} 
przekonanie, że o prawdzie i dobru nie da się nic pewnego powiedzieć. Wszystkie zatem zapatrywania, z jakimi spotykamy się w społecznym dyskursie, są równie prawomocne, gdyż nie istnieje inne - poza wolą większości - kryterium, wedle którego można byłoby rozstrzygać aksjologiczne spory. Zasadność tej tezy wspierać ma twierdzenie, że ludzie, którzy żywią przekonanie, iż znają jakąś ostateczną prawdę, zgodnie z którą życie społeczne i polityczne powinno być uporządkowane - jako niezbyt skłonni do kompromisu w tej kwestii - są w rzeczywistości zagrożeniem dla demokracji ${ }^{28}$. Epistemologiczny i aksjologiczny relatywizm uważa się bowiem za warunek sine qua non tolerancji. „Wspólnym korzeniem wszystkich tych tendencji - stwierdza papież - jest relatywizm etyczny, cechujący znaczną część współczesnej kultury. Można się spotkać z poglądem, że relatywizm ten jest warunkiem demokracji, jako że tylko on miałby gwarantować tolerancję, wzajemny szacunek między ludźmi i uznanie decyzji większości, podczas gdy normy moralne uważane za obiektywne i wiążące prowadziłyby rzekomo do autorytaryzmu i nietolerancji"29.

Zdaniem Jana Pawła II konsekwencją przyjęcia takiego poglądu jest „upartyjnienie” czy té̇ „polityzacja” prawdy. Choć demokracja oparta jest na przekonaniu o równości wszystkich obywateli, w praktyce nie każdy z nich ma jednakowe szanse wpływu na podejmowane decyzje. Ostateczny wynik głosowań nie jest zwykłym zsumowaniem opinii wyborców. Gdyby bowiem w demokracji chodziło o to, aby układ parlamentarny był lustrzanym odbiciem preferencji społeczeństwa, przestarzały mechanizm wyborów należałoby zastąpić bardziej nowoczesnymi narzędziami typu: badanie opinii publicznej przez kilka niezależnych pracowni. Przyniosłoby to zapewne bardzo konkretne oszczędności finansowe, a uniknięto by w ten sposób również zbędnej eskalacji napięć społecznych, jakie nieuchronnie towarzyszą kampaniom wyborczym. Skoro jednak kampanie wyborcze i propaganda polityczna uznawane są za normalne instrumenty

28 Por. CA 46.

${ }^{29}$ „Dziś zwykło się twierdzić, że filozofią i postawą odpowiadającą demokratycznym formom polityki są agnostycyzm i sceptyczny relatywizm, ci zaś, którzy żywią przekonanie, że znają prawdę, i zdecydowanie za nią idą, nie są, z demokratycznego punktu widzenia, godni zaufania, nie godzą się bowiem z tym, że o prawdzie decyduje większość, czy też, że prawda się zmienia w zależności od zmiennej równowagi politycznej” (cA 46). Por. EV 70 . 
demokracji, oznacza to, że dopuszcza się możliwość wpływania na opinie wyborców i zmianę ich sympatii politycznych, i to nie wyłącznie za sprawą racjonalnej argumentacji. Złożoność problemów, nieprzenikliwość procedur podejmowania decyzji, pozostające do dyspozycji elit politycznych i finansowych narzędzia oddziaływania na stan wiedzy i świadomości obywateli sprawiają, że w efekcie - jak zwraca uwagę papież - „postulaty społeczeństwa rozpatruje się nie przy użyciu kryteriów sprawiedliwości i moralności, ale raczej biorąc pod uwagę siłę wyborczą lub finansową stojących za nimi grup"30. W politycznej grze dochodzi do instrumentalizacji idei i przekonań do celów, jakie stawiają sobie strony walczące o władzę i wpływy. Ostatecznie oznacza to, iż w miejsce wartości stanowiących tradycyjne kryterium rozstrzygania sporów wchodzi kryterium siły. Nie chodzi tu oczywiście o „nagą przemoc”, ale o siłę finansów, organizacji czy propagandy. Wszystko wówczas staje się dopuszczalnym przedmiotem umowy, negocjacji, kompromisu. W efekcie prawo, podporządkowane woli silniejszego, przestaje być prawem, demokracja - demokracją, a państwo - „wspólnym domem”. Przekształca się ono w „państwo tyrańskie”, uzurpujące sobie prawo do dysponowania życiem i losem słabszych „w imię pożytku społecznego, który w rzeczywistości oznacza jedynie interes jakiejś grupy"31. Ponieważ nie istnieje żadne obiektywne kryterium, do którego mogliby się odwołać pokonani w grze wyborczej, zmuszeni są oni do bezwzględnego podporządkowania się woli zwycięzców. Może to oznaczać także konieczność podporządkowania własnego sumienia. Ryzyko takiego scenariusza zwiększa się wraz $z$ dążeniem do oparcia finalnej decyzji na konsensusie. Brak obiektywnego kryterium, pozwalajacego uzasadnić sprzeciw wobec „woli wszystkich”, oznacza, że ten, kto uparcie broni swojej pozycji, w istocie broni jedynie egoistycznego interesu swojej grupy wbrew interesowi ogółu.

\section{Sumienie podporządkowane woli większości}

Postulat podporządkowania sumienia woli wiekszości potencjalnie jest już zawarty w twierdzeniu o zasadniczej niepoznawalności prawdy i konieczności „ustalania” jej poprzez głosowanie. Jeśli bowiem określona

\footnotetext{
30 CA 47.

31 EV 20.
} 
wolą większości „prawda” miałaby być jedyną mającą prawo obywatelstwa w sferze publicznej, polityk i w ogóle każdy, kto wkraczałby w tę sferę, zmuszony byłby ją „,respektować", to znaczy podporządkować jej własne sumienie. W liberalnej demokracji dają się zatem zaobserwować dwie na pozór diametralnie sprzeczne tendencje. „Z jednej strony - zauważa Jan Paweł II - pojedyncze osoby roszczą sobie prawo do całkowitej autonomii moralnego wyboru i żądają od państwa, aby nie opowiadało się po stronie żadnej określonej koncepcji etycznej i nie narzucało jej innym, ale by ograniczyło się do zapewnienia każdemu możliwie jak największej przestrzeni wolności, której jedynym ograniczeniem zewnętrznym jest zasada nienaruszania przestrzeni autonomii, do jakiej ma prawo każdy inny obywatel. Z drugiej strony uważa się, że szacunek dla wolności wyboru innych wymaga, aby w sprawowaniu funkcji publicznych i zawodowych nikt nie kierował się własnymi przekonaniami, ale każdy starał się spełniać wszelkie żądania obywateli, uznawane i gwarantowane przez ustawy prawne, przyjmując jako jedyne kryterium moralne w wypełnianiu swoich funkcji to, co zostało określone w tychże ustawach. W ten sposób odpowiedzialność osoby zostaje powierzona prawu cywilnemu, co oznacza rezygnację z własnego sumienia przynajmniej w sferze działalności publicznej" ${ }^{\prime 2}$. Paradoksalnie zatem wykluczenie sumienia ze sfery publicznej w imię poszerzenia obszaru indywidualnej wolności prowadzi do eliminacji sumienia z życia jednostki i ograniczenia jej sfery wolności wszędzie tam, gdzie wykonuje ona funkcje publiczne i gdzie styka się z prawem pretendującym do bycia aksjologicznie neutralnym.

Stosunek do sumienia obywateli ma podstawowe znaczenie z punktu widzenia trwałości demokracji. Nie przypadkiem pewien totalitarny przywódca postawił sobie za cel uwolnienie człowieka od sumienia: „Wyswobadzam człowieka od presji ducha, który stał się celem samym w sobie; od brudnego i upokarzającego samoudręczenia powodowanego przez chimerę zwaną sumieniem i moralnością, i do roszczeń do wolności i samodzielności osobistej, do której i tak dorastają tylko nieliczni” - miał powiedzieć Adolf $\mathrm{Hitler}^{33}$. „Unicestwienie sumienia - komentuje kard.

\footnotetext{
32 EV 69.

${ }^{33}$ Cytat ma pochodzić z rozmowy Adolfa Hitlera z Hermannem Rauschningiem, prezesem Senatu Wolnego Miasta Gdańska w latach 1933-1934. Zanotowany jest w: T. Schie-
} 
Ratzinger - jest warunkiem wstępnym poddania się totalitaryzmowi i panowania totalitaryzmu" 34 .

\section{Związki demokracji z totalitaryzmem}

Refleksja nad współczesną demokracją i jej słabnącymi więzami z absolutnymi wartościami prowadzi Jana Pawła II do postawienia radykalnej tezy, iż „demokracja bez wartości łatwo przemienia się w jawny lub zakamuflowany totalitaryzm" ${ }^{35}$. Wydaje się, że myśl tę można rozważać w kontekście odkrytej już przez starożytnych tendencji wszystkich ustrojów do samozniszczenia. Ów wewnętrzny mechanizm degeneracji ustrojów dotyczy także demokracji, która - jak to wyraził Charles Taylor - „nie została zapisana w naszych genach" ${ }^{36}$. Najstarszą bodaj jego analizę, autorstwa Platona, spotykamy w VIII księdze Państwa ${ }^{37}$. Arystokracja - jak dowiadujemy się ze sporządzonego w formie karykatury opisu - ulega rozpadowi, przekształcając się w timokrację, która nieuchronnie zmierza ku oligarchii, aby następnie przemienić się w demokrację, która stacza się nieodwołalnie ku tyranii. Z procesu tego nie są wyłączone nawet twory idealne, gdyż „wszystko, co powstaje, ginąć musi, więc nawet i taka budowla całego czasu nie przetrzyma, tylko się rozpadnie kiedyś" $(546 a)^{38}$. Zadanie filozofa sprowadza się zatem do odkrycia wewnętrznych mechanizmów autodestrukcji, co - być może - pozwoli przedłużyć żywotność danego ustroju dzięki wprowadzeniu doń elementów opóźniających ów proces. Platon stawia tezę, iż ustroje - mówiąc kolokwialnie - podobnie jak ryby, psują się od głowy. W Państwie zawarte jest jednoznaczne ostrzeżenie: „przewrót każdego ustroju państwowego wychodzi właśnie od tego czynnika, który ma rządy w ręku, kiedy się w nim zaczną rozterki wewnętrzne" (545c). Państwo zatem, czy też jego

der, Hermann Rauschnings „Gespräche mit Hitler” als Geschichtsquelle, Opladen 1972, s. 19, przyp. 25, cyt. za: J. Ratzinger, Kościót - ekumenizm - polityka, s. 212.

${ }^{34}$ J. Ratzinger, Kościót - ekumenizm - polityka, s. 212.

${ }^{35}$ CA 46.

${ }^{36}$ C. Taylor, Kiedy mówimy: społeczeństwo obywatelskie, w: Rozmowy w Castel Gandolfo, t. 1, red. K. Michalski, Warszawa-Kraków 2010, s. 548.

${ }^{37}$ Szerzej: P. Mazurkiewicz, Przemoc w polityce, Wrocław-Warszawa-Kraków 2006, S. $171-185$.

${ }^{38}$ Cytaty według: Platon, Państwo, tłum., wstęp i koment. W. Witwicki, Kęty 2003. 
ustrój, degeneruje się, począwszy od grupy, która aktualnie dzierży ster władzy. Ponieważ „ustroje powstają [...] z obyczajów tych ludzi, którzy są w państwach" (544d), tzn. ponoszą aktualnie odpowiedzialność za państwo, ostatecznie jego losy zależą od ich charakteru czy - jak wyraża to Platon - od „struktury duchowej ludzi prywatnych” (544e). Gdy ginie umiłowanie mądrości wśród filozofów, z powierzchni znika państwo idealne. Gdy zanika umiłowanie cnoty (areté) wśród arystokracji, obumiera ustrój arystokratyczny. Gdy ludzi opuszcza ambicja i zastępuje ją „,dziki kult dla złota i srebra” (548a), rozpadowi ulega timokracja. Gdy ludzie są już tak popsuci, że nawet pieniądza nie cenią, lecz marnotrawią majątki w pogoni za chwilowymi przyjemnościami, na scenę wkracza demokracja, jako ustrój, w którym nie istnieje żadne kryterium dopuszczania do udziału w rządzeniu. Dostęp do władzy - teoretycznie mają wszyscy. Poszerzanie elity, której powierza się odpowiedzialność za państwo, dokonuje się za sprawą obniżania stawianych jej wymagań. Sama zaś elita sprawująca władzę w każdym z ustrojów ulega procesowi duchowej degradacji. Z młodych ludzi najpierw robi się „niewieściuchów i pieszczochów niezdolnych do wszelkiego trudu fizycznego i duchowego, zbyt miękkich na to, żeby mieć moc nad przyjemnościami i nad przykrościami, i próżniaków" (556b). Gdy dochodzi już do ustanowienia demokracji, ludzie zamiast korzystać w wolności, upijają się „wolnością nierozcieńczoną" (562d). Państwo staje się pobłażliwe nawet dla przestępców. Do władzy dopuszcza się każdego, „byleby tylko oświadczył, że kocha Lud" (558c). Następuje upadek autorytetów do tego stopnia, że "nauczyciel boi się uczniów i zaczyna im pochlebiać, a uczniowie nic sobie nie robią z nauczyciela" (563a). Dochodzi nawet do tego, że to nie młodzi uczą się od starszych, ale starzy ludzie naśladują młodych, „żeby nie wyglądać ponuro i nie mieć zbyt władczej postawy” (563b). $\mathrm{Na}$ wszystko nakłada się erozja języka, tak że zwyczajną butę nazywa się „wyższą kulturą, nierząd - niezależnością, beznadziejną rozpustę pańskim gestem, a bezczelność - męstwem" (560e). W państwie tak ceni się wolność, że cieszą się nią nawet zwierzęta. Platon pisze: „Bo jeżeli chodzi o zwierzęta, które ludzie chowają, to o ile są bardziej swobodne tam, niż gdzie indziej, w to by nikt nie uwierzył, kto by tego sam nie doświadczył. Po prostu suki prowadzą się tam, zgodnie z przysłowiem, całkiem tak jak ich panie, a zdarzają się też konie i osły przyzwyczajone do tego, żeby się poruszać po drogach bardzo swobodnie i z godnością, 
i wpadają na każdego przechodnia, jeżeli im nie ustąpi. I w ogóle w ten sposób, gdzie się tylko ruszyć, wszędzie pełno wolności” (563c-d).

Skoro w demokracji tak wielkie jest umiłowanie wolności, dlaczego Platon umieszcza ją w sąsiedztwie dyktatury? Jego wykład jest w tym miejscu bardzo klarowny. To nie $\mathrm{z}$ innego ustroju powstaje dyktatura, jak tylko z demokracji. Jako że wszelki nadmiar lubi obracać się w swoje przeciwieństwo, to właśnie $\mathrm{z}$ wolności bez granic powstaje niewola najzupełniejsza i najdziksza (por. 563e-564a). Mechanizm jest bardzo prosty. Ponieważ w demokracji wolno wszystko, istnieją w niej również zarodki dyktatury. Jej sympatycy nie są niebezpieczni tak długo, jak długo obywatele rzeczywiście cenią sobie wolność, tzn. gotowi są do ponoszenia ofiar w jej obronie. Skoro jednak ich dusza „robi się tak delikatna i wrażliwa, że choćby im ktoś tylko odrobinę przymusu próbował narzucić, gniewają się i nie znoszą" (563d), nie będą gotowi do podjęcia żadnych wyrzeczeń w obronie wolności. W tym właśnie kryje się rzeczywiste niebezpieczeństwo przekształcenia się demokracji w jej przeciwieństwo.

\section{Granice wspólnoty: równość i zakaz dyskryminacji}

Tezie, iż relatywizm etyczny jest warunkiem koniecznym wzajemnego szacunku między ludźmi, tolerancji, a wreszcie samej demokracji, Jan Paweł II przeciwstawia analizę sytuacji ludzi najsłabszych w zachodnich społeczeństwach. Brak odniesienia do obiektywnych wartości powoduje, że wszystko staje się przedmiotem umowy i negocjacji, w tym także prawa najsłabszych ${ }^{39}$. Pojawia się więc pytanie o granice demokratycznej wspólnoty i o prawa tych, którzy nie mają wystarczającej siły, by skutecznie bronić swoich praw (dzieci, starcy, osoby chore i upośledzone). Leszek Kołakowski stawiał swego czasu pytanie o miejsce dzieci w filozofii liberalnej, zważywszy, że w pewnych sytuacjach (np. obowiązek szkolny czy decyzje dotyczące podejmowania współżycia seksualnego) rozsądek podpowiada, że z zasady powinny one być pozbawione możliwości podejmowania autonomicznych decyzji ${ }^{40}$. Są zatem pełnoprawnymi członkami liberalnej wspólnoty czy też nie? Ojciec święty kieruje szczególną uwagę na ludzi w sytuacjach „krańcowych”, tzn. u początku

\footnotetext{
39 Por. EV 20.

${ }^{40}$ L. Kołakowski, Moje słuszne poglądy na wszystko, Kraków 1999, s. 164-185.
} 
i u kresu życia. Zdaniem papieża poszanowanie ich praw jest prawdziwym miernikiem demokracji. Problematyka szacunku dla życia pozwala dostrzec dwuznaczności i sprzeczności - a w ślad za nimi przerażające konsekwencje praktyczne - jakie niesie ze sobą próba konstruowania demokracji w powiązaniu z relatywizmem etycznym. „Czyż można mówić o godności każdej osoby, kiedy pozwala się na zabijanie tej najsłabszej i najbardziej niewinnej? W imię jakiej sprawiedliwości poddaje się osoby najbardziej niesprawiedliwej dyskryminacji, uznając niektóre z nich za godne obrony, a odmawiając tej godności innym?" ${ }^{41}$ Czy taki ustrój wciąż można określać mianem demokracji? Czy nie mamy tu do czynienia raczej z „demokratyczną zdradą” człowieka - pyta George Weigel ${ }^{42}$ ? „To prawda - czytamy w Evangelium vitae - że historia zna przypadki zbrodni dokonywanych w imię "prawdy». Ale do czynów równie zbrodniczych i do radykalnego pogwałcenia wolności dochodziło też i nadal dochodzi pod wpływem «relatywizmu etycznego». Gdy większość parlamentarna lub społeczna uchwala, że zabicie jeszcze nie narodzonego życia ludzkiego jest prawnie dopuszczalne, choćby nawet pod pewnymi warunkami, to czyż nie podejmuje tym samym decyzji «tyrańskiej» wobec najsłabszej i najbardziej bezbronnej ludzkiej istoty? Sumienie powszechne słusznie wzdryga się w obliczu zbrodni przeciw ludzkości, które stały się tak smutnym doświadczeniem naszego stulecia. Czyż te zbrodnie przestałyby być zbrodniami, gdyby nie popełnili ich pozbawieni skrupułów dyktatorzy, ale gdyby nadała im prawomocność zgoda większości?”³

\section{Autentyczna demokracja a idea władzy ograniczonej}

O wartości ustroju - zdaniem papieża - nie decydują formalne procedury wyłaniania władzy ani wielkość grupy dopuszczonej do udziału w niej, ale jej treść. Jeśli demokracja liberalna pojawiła się jako wyraz sprzeciwu wobec istnienia w państwie władzy absolutnej, oznacza to,

41 EV 20.

${ }^{42}$ Por. G. Weigel, „Centesimus annus” a przyszłość demokracji: powtórna lektura, w: Jan Paweł II, „Centesimus annus”. Tekst i komentarze, red. F. Kampka, C. Ritter, Lublin 1998, s. 127.

${ }^{43} \mathrm{EV} 7 \mathrm{O}$. 
że również społeczeństwo, lud czy naród, będący suwerenem w ustroju demokratycznym, nie powinien posiadać absolutnych uprawnień. Wydaje się, że w definicję demokracji - tak jak ją rozumiemy na Zachodzie - wpisana jest idea władzy ograniczonej, i to nie tylko formalnie, ale przede wszystkim istotowo, tzn. z samej swojej natury. Ograniczenie natury formalnej wynika z przyjętej za podstawę demokracji koncepcji państwa prawnego, w którym „najwyższą władzę ma prawo, a nie samowola ludzi" ${ }^{44}$. Ograniczenie treściowe wynika ze związania demokracji z poprawną koncepcją osoby ludzkiej, która jest podmiotem niezależnych od państwa niezbywalnych praw. „Autentyczna demokracja - czytamy w Centesimus annus - możliwa jest tylko w Państwie prawnym i w oparciu o poprawną koncepcję osoby ludzkiej”"45. Poprawny ustrój buduje się więc - zdaniem papieża - oddolnie, poczynając od poprawnej koncepcji osoby ludzkiej. Przyjęcie w punkcie wyjścia błędnej koncepcji człowieka (tzw. błąd antropologiczny) prowadzi w efekcie - jak miało to miejsce w przypadku komunizmu i socjalizmu - do błędnej, tzn. utopijnej wizji życia społecznego i politycznego, czego skutkiem jest użycie jakiejś formy przemocy w trakcie prób jej urzeczywistniania ${ }^{46}$. W tym właśnie kontekście Ojciec święty osadza swoją refleksję nad przemocą wobec nienarodzonych dzieci, z jaką spotykamy się w społeczeństwach zachodnich. Kiedy bowiem następuje przyjęcie zgodnie z tak zwanymi demokratycznymi zasadami praw dopuszczających przerywanie ciąży lub eutanazję, mamy w rzeczywistości do czynienia jedynie $\mathrm{z}$ „tragicznym pozorem praworządności, zaś ideał demokratyczny - jak stwierdza Jan Paweł II - [...] zostaje zdradzony u samych podstaw [...]. Rewindykacja

44 CA 44.

${ }^{45}$ CA 46. Jan Paweł II podejmował próby wyartykułowania zbioru wartości szczegółowych wynikających z przyjęcia prawidłowej koncepcji człowieka. Przykładowo w Veritatis splendor czytamy: „W odniesieniu do dziedziny polityki należy podkreślić, że uczciwość w kontaktach między rządzącymi a rządzonymi, jawność w administracji publicznej, bezstronność w rozstrzyganiu spraw publicznych, poszanowanie praw przeciwników politycznych, ochrona praw ludzi oskarżonych w procesach i sądach doraźnych, sprawiedliwe i uczciwe wykorzystanie pieniędzy publicznych, odrzucenie niegodziwych metod zdobywania, utrzymywania i poszerzania władzy za wszelką cenę - to zasady, które znajdują swe najgłębsze źródło, a jednocześnie uzasadnienie swej szczególnej ważności, w transcendentnej wartości osoby i w obiektywnych nakazach moralnych, dotyczących funkcjonowania państw” (vs 101).

46 Por. CA 44. 
prawa do przerywania ciąży, dzieciobójstwa i eutanazji oraz prawne jego uznanie jest - jak czytamy w Evangelium vitae - równoznaczne z przyjęciem wynaturzonej i nikczemnej wizji ludzkiej wolności: z uznaniem jej za absolutną władzę nad innymi i przeciw innym" "47. Są to zatem pierwsze symptomy wskazujące na to, że „działają już mechanizmy, które prowadzą do zaniku prawdziwego ludzkiego współżycia i do rozpadu samego organizmu państwowego" ${ }^{48}$.

Państwo praworządne to państwo, w którym nie tylko istnieje trójpodział władz, ale w którym przede wszystkim „najwyższą władzę ma prawo, a nie samowola ludzi”"49. Równość wobec prawa jest także równością wobec prawa moralnego. Nikomu nie wolno więcej niż innym, także $\mathrm{w}$ dziedzinie moralności. Nikt nie jest zwolniony z przestrzegania norm moralnych. „Moralna deregulacja” ${ }^{50}$ demokratycznego systemu sprawia, że to nie prawo rządzi w społeczeństwie, ale siła wyborcza, finansowa czy inna ${ }^{51}$.

\section{Klasyczna teoria praworządności}

Lansowana w ramach teorii demokracji papieska wizja państwa praworządnego zdaje się ściśle nawiązywać do klasycznej teorii praworządności sformułowanej przez Arystotelesa. W Iv księdze Polityki Stagiryta zwraca uwagę na dwa aspekty praworządności/eunomii. „A nie jest to praworządność - czytamy tam - gdy wprawdzie prawa są dobre, ale nie znajdują posłuchu. Dlatego jako jedną cechę praworządności przyjąć należy posłuszeństwo wobec istniejących praw; druga zaś wyraża się w tym, że prawa, którym obywatele podlegają, są dobrze ujęte (bo przecież można słuchać także i źle ujętych praw)" ${ }^{2}$. Praworządność/eunomia zatem w tradycji klasycznej oznacza posłuszeństwo dobremu prawu. Wzajemne związanie w ramach idei demokracji w ujęciu Jana Pawła II aspektu prawnego z antropologicznym wydaje się mieć na celu urzeczywistnienie tak właśnie

47 EV 20.

48 Tamże.

49 CA 44.

50 G. Weigel, „Centesimus annus” a przyszłość demokracji..., s. 125.

${ }^{51}$ Por. CA 47.

${ }^{52}$ Arystoteles, Polityka, tłum. i przypisy L. Piotrowicz, wstęp K. Grzybowski, Warszawa 1964 , s. 167. 
pojmowanej praworządności. W przypadku demokracji ma to szczególne znaczenie, jako że jest ona najbardziej kruchym, a zarazem najbardziej wymagającym ze wszystkich możliwych ustrojów. Najbardziej wymagającym, gdyż - jeśli słuszne jest wspomniane wyżej połączenie formy ustrojowej państwa ze „strukturą duchową ludzi prywatnych” czy też, jak dzisiaj byśmy raczej powiedzieli: $\mathrm{z}$ mentalnością ludzi należących do elity politycznej - w przypadku demokracji elita ponosząca odpowiedzialność za państwo jest najszerszą z możliwych, gdyż są nią z założenia wszyscy obywatele. Jest demokracja jednocześnie najbardziej kruchym z ustrojów państwowych z uwagi na to, że aby właściwie funkcjonowała, dojść musi do pogodzenia dwóch sprzecznych ze sobą idei: zasady większości oraz przekonania o istnieniu absolutnych, niezależnych od opinii większości wartości. W konsekwencji wyrosła na podłożu chrześcijańskiej tradycji demokracja jawi się jako swoisty „pożeracz wartości”. Zniszczenia, jakie jej codzienne funkcjonowanie powoduje w świadomości moralnej społeczeństwa, nie powinny jednak wzbudzać szczególnego niepokoju, gdyż w normalnych warunkach - owo podłoże okazuje się tkanką odnawiającą się od dołu, niczym naskórek na spracowanej dłoni. Los państwa - jak zauważa Ernst-Wolfgang Böckenförde - zależy od funkcjonowania w nim absolutnych wartości, których ono, jako neutralne światopoglądowo, nie wytwarza, a które pojawiają się w nim niejako spontanicznie dzięki działalności Kościołów ${ }^{53}$. Wspomniane wyżej problemy z demokracją zaczynają się zatem dopiero wówczas, gdy zaczyna dawać o sobie znać zjawisko dechrystianizacji społeczeństw, tzn. gdy słabną religijne motywacje obywateli. Stąd pytanie: czy zachodnia demokracja przetrwa epokę sekularyzacji? Czy „defekt sceptycznego relatywizmu” ${ }^{54}$ nie doprowadzi do całkowitej autodestrukcji systemu? W religii bowiem, z jej koncepcją praw Boga, znajdują się swoiste ograniczniki dla ludzkiej samowoli. Wbudowane w świadomość ludzi religijnych „bezpieczniki”, chroniące przed przekroczeniem kompetencji przez władzę/człowieka, zapobiegają przekształceniu się prawdziwej demokracji w dyktaturę większości. Kryzys zatem, jaki zagraża społeczeństwom zachodnim - zdaniem Jana

\footnotetext{
${ }^{53}$ Por. E.-W. Böckenförde, Wolność - państwo - Kościót, wybór i tłum. P. Kaczorowski, wsprowadzenie J. Tischner, Kraków 1994, s. 120.

${ }^{54}$ G. Weigel, „Centesimus annus” a przyszłość demokracji..., s. 124.
} 
Pawła II - nie jest w swej istocie kryzysem politycznym, lecz metafizycznym ${ }^{55}$. Przyszłość tej części świata zależeć więc będzie nie tyle od wysiłku włożonego w udoskonalanie demokratycznych instytucji, ile od odpowiedzi, jakiej udzielą społeczeństwa na pytanie o miejsce Boga w życiu publicznym i o koncepcję człowieka, jego praw i granic jego wolności.

\section{Bibliografia}

Arendt H., Korzenie totalitaryzmu, t. 2, tłum. D. Grinberg, M. Szawiel, Kwartalnik Polityczny „Krytyka”, Warszawa 1989.

Arystoteles, Dzieła wszystkie, t. 2, tłum. K. Leśniak i in., Wydawnictwo Naukowe PWN, Warszawa 1990; t. 5, tłum. D. Gromska, L. Regner, W. Wróblewski, Warszawa 1996; t. 7, Warszawa 1994.

Arystoteles, Polityka, tłum. i przypisy L. Piotrowicz, wstęp K. Grzybowski, Państwowe Wydawnictwo Naukowe, Warszawa 1964.

Bénéton P., Introduction à la politique, Presses Universitaires de France, Paris 1997.

Böckenförde E.-W., Wolność - państwo - Kościót, wybór i tłum. P. Kaczorowski, wsprowadzenie J. Tischner, Wydawnictwo Znak, Kraków 1994.

Jan Paweł II, Posynodalna adhortacja apostolska Ecclesia in Africa, Libreria Editrice Vaticana, Watykan 1995.

Jan Paweł II, Encyklika Centesimus annus, przedruk: Libreria Editrice Vaticana, Włocławek 1991.

Jan Paweł II, Encyklika Evangelium vitae, Libreria Editrice Vaticana, Watykan 1995.

Jan Paweł II, Encyklika Veritatis splendor, Pallottinum, Poznań 1993.

Kołakowski L., Moje słuszne poglady na wszystko, Wydawnictwo Znak, Kraków 1999.

Mazurkiewicz P., Etyczne podstawy demokracji według Jana Pawła II, w: Po przełomie. Przełom wieku w kulturze - kultura na przełomie wieków, red. A. Żylińska, A. Skrendo, Wydawnictwo Publisher's, Szczecin 2001, s. 19-30.

Mazurkiewicz P., Niepolityczna polityczność Kościoła, w: 50 lat później. Posoborowe dylematy wspótczesnego Kościoła, red. J. Grosfeld, Instytut Politologii Uniwersytet Kardynała Stefana Wyszyńskiego - Centrum Myśli Jana Pawła II, Warszawa 2014, s. 131-145.

55 J.-B. d'Onorio, Jean Paul II et l'éthique politique, Paris 1992, s. 170. 
Mazurkiewicz P., Przemoc w polityce, Zakład Narodowy im. Ossolińskich - Wydawnictwo, Wrocław-Warszawa-Kraków 2006.

Narecki K., Słownik terminów Arystotelesowych, w: Arystoteles, Dzieła wszystkie, t. 7, Wydawnictwo Naukowe PwN, Warszawa 1994, s. 11-127.

Onorio J.-B. d', Jean Paul II et l'éthique politique, Éditions Universitaires, Paris 1992.

Platon, Państwo, tłum., wstęp i koment. W. Witwicki, Wydawnictwo Antyk, Kęty 2003.

Ratzinger J., Kościół - ekumenizm - polityka, Pallottinum, Warszawa-Poznań 1990.

Taylor C., Kiedy mówimy: społeczeństwo obywatelskie, tłum. A. Pawelec w: Rozmowy w Castel Gandolfo, t. 1, red. K. Michalski, Centrum Myśli Jana Pawła II Wydawnictwo Znak, Warszawa-Kraków 2010, s. 543-56o.

Weigel G., „Centesimus annus” a przyszłość demokracji: powtórna lektura, w: Jan Paweł II, „Centesimus annus”. Tekst i komentarze, red. F. Kampka, C. Ritter, Redakcja Wydawnictw KUL, Lublin 1998, s. 115-131.

\begin{abstract}
Abstrakt
Autor podejmuje refleksję nad politycznym przesłaniem encykliki Centesimus annus. Zawarte jest ono w dwóch rozdziałach papieskiego dokumentu: poświęconemu analizie wydarzeń roku 1989 oraz relacji państwo-kultura. W odniesieniu do pierwszej kwestii autor podejmuje zagadnienie realizmu politycznego oraz ryzyka przekształcania się polityki w świecką religię. W odniesieniu do drugiej analizuje pozytywne i krytyczne aspekty papieskiego spojrzenia na demokrację, aksjologicznych fundamentów demokracji, wolności sumienia, przynależności do demokratycznej wspólnoty, idei władzy ograniczonej, praworządności oraz mechanizmów korupcji ustroju demokratycznego.
\end{abstract}

\title{
Political message of the encyclical Centesimus annus
}

\author{
Abstract \\ The author reflects on the political message of the encyclical Centesimus annus. \\ It is expressed in two chapters of the papal document: devoted to the analysis \\ of the events of 1989 and to the state - culture relations. With regard to the first
}


issue by tackling the problem of political realism and the risk of transformation of politics in a secular religion. For the second examines the positive and critical aspects of the Pope's perception of democracy, the axiological foundations of democracy, freedom of conscience, the issue of belonging to a democratic community, the idea of limited government, the rule of law and the mechanisms of corruption of the democratic system. 